\title{
Grafting New Values into Public Institutions by Reforming the Accounting System: Lessons Learned from the Italian Higher Education System
}

\author{
Guido Modugno ${ }^{1}$, Ferdinando Di Carlo ${ }^{2}$, Manuela Lucchese ${ }^{3} \&$ Tommaso Agasisti ${ }^{4}$ \\ ${ }^{1}$ Department of Economics, Business, Mathematics and Statistics, University of Trieste, Trieste, Italy \\ ${ }^{2}$ Department of Mathematics, Computer science and Economics, University of Basilicata, Potenza, Italy \\ ${ }^{3}$ Department of Economics, University of Campania "Luigi Vanvitelli”, Capua (CE). Italy \\ ${ }^{4}$ School of Management, Milan Polytechnic, Milan, Italy \\ Corresponding author: Ferdinando Di Carlo, Department of Mathematics, Computer science and Economics, \\ University of Basilicata, Viale dell’Ateneo Lucano, Potenza, Italy. E-mail: ferdinando.dicarlo@unibas.it
}

Received: April 3, 2020

doi:10.5539/ijbm.v15n7p20

\author{
Accepted: May 10, 2020 \\ Online Published: June 3, 2020 \\ URL: https://doi.org/10.5539/ijbm.v15n7p20
}

\begin{abstract}
The paper wants to highlight some accounting practices in the early stage of the adoption of accrual accounting in Higher Education Institutions. The accounting reform was one of the core aspects of a process of enforced hybridization of HE institutions. Exogenous and endogenous (organizational) issues emerge, that undermine transparency and comparability of accounting information. Based on structured interviews in 14 Italian universities, the paper provides evidences of the main aspects that hinder the transparency and the comparability of accounting information with the risk to deprive the new accounting rules of their potential for change. Resistance to change could be observed, resulting in a partial or distorted adoption of the new accounting rules: some practices, in particular, aimed at safeguarding the interests of a particular group. The paper propitiates further research based on case studies aiming at understanding how public organizations tend to design internal accounting procedures that preserve the prerogatives of particular groups within the organization. The research overturns the rhetoric of the adoption of managerial practices for the enhancement of efficiency, effectiveness and economy by showing how organizations shape these practices in order to keep the status quo unchanged.
\end{abstract}

Keywords: accrual accounting, financial information transparency, comparability, institutional complexity, hybridity, higher education

\section{Introduction}

The paper investigates the factors that hinders comparability and transparency of financial reporting in a public setting characterized by great autonomy in operations and long-term projects. The analysis considers the accounting policies adopted by 14 Italian universities immediately after the shift from commitment-basis to accrual accounting.

Italy reformed its Higher Education system in 2010 (law nr. 240). With reference to accounting issues, the reform aimed at 'ensuring the transparency and homogeneity of accounting systems and procedures, and at enabling the assessment of the financial sustainability as well as of the net assets of Higher Education Institutions (HEIs)'. According to the expectations of the legislator, the transition to the new accrual-based accounting system improves the quality and the relevance of financial information and enhances the capability of university governing bodies and of the Ministry of University and Research (MIUR) to take decisions. However, findings reveal that different kinds of factors hampered these achievements. The analysis focuses on the most innovative aspects of the reform: (a) the measurement of the financial performance, which was ignored in the former accounting system, and (b) the greater importance given to entity-wide financial statements rather than to the financial statements of the organizational units, i.e. the departments. The article wants to shed light on the factors that may deprive the shift to accrual accounting of expected benefits such as comparability and transparency of accounting information.

The first studies on comparability of accounting information date back to the sixties (Simmons, 1967). More 
recent studies consider the process of accounting harmonization and the impact of IFRS (Yip \& Young, 2012) and IPSAS on the quality of financial information (Benito, Brusca \& Montesinos, 2007; Caperchione. \& Lapsley, 2011; Brusca \& Martinez, 2016; Christiaens \& Neyt, 2015). The measurement of the degree of comparability of financial information (van der Tas, 1988; Krisement, 1997) and its value for investors (De Franco, Kothari \& Verdi, 2011) are other major issues, as well as comparability between public organisations and corporations. Thus, comparability is mostly considered from a multinational/multi-sectorial perspective: there are few examples of studies on comparability within a specific sector at local level (Christiaens \& Neyt, 2015) and on the factors that hinder it. It is generally assumed that using common accounting rules brings to comparability: however, rules often lack definition in the early phase of a process of accounting change. This can undermine conditions of comparability even at local level (Christiaens \& de Wielemaker, 2003).

The subject of transparency of financial information is even more faceted: the understandability of financial statements and budgets, accountability on expected results, as well as the determinants of the perceived quality of financial information are all issues associated to transparency (Guillamòn, Benito \& Bastida, 2011; Rodríguez Bolívar, Alcaide Muñoz \& López Hernández, 2013; da Cruz, Tavares, Marques, Jorge \& De Sousa, 2016). In the perspective adopted here, transparency is considered as the conjunct effect of several factors that enable decision making and reduces undesirable bias in financial statements: quality and completeness of financial information, understandability, adherence to high quality accounting standards (Stein, Salterio \& Shearer 2017).

The accounting reform formally reflected the pressures for more competitive and financially sustainable (i.e. less dependent on government transfers) universities providing increased quality and accessibility of higher education services. Thus, we consider that the shift to accrual accounting was not a neutral or merely 'technical' issue: in Italy, vast parts of the HE academic and administrative staff considered this reform as contrasting with the public nature of universities due to its inherence to the logics of the market. While individual autonomy, academic authority and informality prevail in $\mathrm{HE}$, the managerial culture inherent in accrual accounting emphasizes collective engagement, administrative authority and formality (Christopher, 2012). The shift from input-based to performance-based funding further accentuated the pressure exerted by the Ministry of University and Research (MIUR) aiming at introducing new institutional logics in the sector. Imposing the adoption of accrual accounting represented the tip of the iceberg in a situation of institutional complexity: universities had to respond to multiple institutional logics.

The paper is organized as follows: literature is examined in the subsequent section, whereas section 3 introduces the objectives and the main features of the reform of HEIs in Italy, with specific reference to the accounting system. The following sections are dedicated respectively to the methodology, the presentation of the evidences emerged from the interviews as well from the documentary analysis, and to the discussion of the problems detected. The last section sets out the conclusions.

\section{Literature Review}

Compared to cash and commitment accounting, public sector accrual accounting (PSAA) is often accredited to provide more complete and relevant financial information; furthermore, it would enhance comparability with for-profit entities, contribute to efficiency improvements (Mathiasen, 1999). financial sustainability, intergenerational equity (Robinson, 1998). Over the years, however, there has been no single consensus on the role of PSAA (Lapsley, Mussari \& Paulsson, 2009; Broadbent \& Guthrie, 2008); moreover, supporters of PSAA mostly rely on 'normative views often presented in a zealous manner' (Christensen, 2007).

With reference to comparability, the most celebrated advantage attributed to PSAA is the possibility to make comparisons between for-profit entities and public organizations (Regan, 1987). This school of thought, often referred to as 'sector neutrality', postulates that one essential body of accounting and reporting rules ought to function equally well for both private and public-sector applications (MacIntosh, 1999; McGregor, 1999; Micallef \& Peirson, 1997). However, this idea is based upon the simplistic assumption of commonalities with the private sector (Lapsley et al., 2009): it has been argued that the services delivered, the organizational goals (Christiaens \& Rommel, 2008) and even the assets (Barton, 1999a, 1999b and 2002; and Carnegie \& Wolnizer, 1999 ) in the public context are so fundamentally dissimilar from those of the private sector, that a different set of rules should be implemented (see, for instance, Carnegie \& West, 2003; Pallot, 2003). In the case of Italian HE, the new accounting rules imposed by the legislator reproduce the norms applicable to corporations: however, specific accounting standards that have no correspondence in the private sector are used for research projects and for the equity. Comparability with for-profit entities was not the main issue: rather, the Ministry gave relevance to the comparability among universities' financial statements.

PSAA is also expected to improve transparency and accountability, due to the possibility to compare costs with outputs (Evans, 1995; Christiaens \& Rommel, 2008; IFAC, 2005). Blöndal (2003) suggests that the main benefit 
expected from using accrual accounting is the disclosure of the true costs of public organisations that commitment accounting distorts or even ignores (Bowerman \& Humphrey, 2001; Neale \& Pallot, 2001; Walker, 2011). These achievements, however, are debateable (Carlin, 2005): Christiaens \& Rommel (2008) observe criticism by public managers and policymakers about the intelligibility of accrual-based accounting information. Cash-based or commitment reporting is reputed more intelligible and relevant to stakeholders thanks to its simplicity and objectivity (Hyndman \& Connolly, 2011; Pina, Torres \& Yetano, 2009). In HE, scholars deal with financial data with the main purpose of being aware of the funds available for the research projects: commitment accounting makes this information more accessible, since it provides a unique authorising budgetary system for operating and investing expenditures.

According to Paulsson (2006). the need for accounting information to support the performance management system was the main official argument for accrual accounting when the technique was introduced in Sweden, in the early 1990s. However, the adoption of managerial practices such as cost accounting in public administration is likely to remain symbolic or ceremonial: their introduction would be functional to the enhancement of the organization's appearance of rationality and efficiency, thus supporting their legitimacy (Di Maggio \& Powell, 1983; Geiger \& Ittner, 1996; Guthrie, 1998). In this perspective, the use of business-like accounting systems in public organisations produces a disjuncture between how accounts measure success and the qualitative criteria that should be used according to the legal remit of the members of the organization. Norms produce coercive isomorphism (Pollitt \& Bouckaert, 2004): organizations are likely to show little resistance to the implementation of mandated practices, but the change shall be superficial and loosely coupled to participants' actions (Modell, 2002). Thus, using PSAA in public universities offers the appearance rather than the substance of an economically rational basis for decision making (Carruthers \& Espeland, 1991): while conforming to external pressures, HEIs tend to separate their internal activities from the externally focused symbolic systems.

This important body of literature on pros and cons of PSAA assumes that organizations respond uniformly to external pressures: the coercive adoption of accrual accounting would produce similar - although only formal effects by all organizations. In 2015, the conference of the Italian rectors commissioned an extensive study on the implementation of the reform of Italian HE: the study evidenced how, in the presence of the same external pressures, universities adopted different choices with reference to the organizational structure, the decisional processes and the evaluation of human resources. This study didn't consider budgeting and reporting practices (Capano \& Regini, 2015): this may suggest that also in this case, the accounting system was considered a neutral and merely technical issue.

However, literature has evidenced that accounting systems carry their own rationality. While academia is traditionally oriented to creativity, unconventional thought and autonomy, performance-based funding and PSAA bring with them the substantive rationality and legitimized myths of efficiency, value for money, control over the use of public resources and management accountability (Townley, 2002). Business-like planning, accounting and reporting are associated with private sector organization: this association carries implications of an incipient commercialization. In Italy, the shift from input-based funding to performance-based funding further encouraged the perception of this process of commercialization. Implicit in commercialization is that something does not have value in itself; in the market, value is realized through an economic exchange (Townley, 2002). but research and education are traditionally considered as public goods (Ferlie, Musselin \& Andresani, 2008). This idea is strongly ingrained in the Italian academy, so that the dependence of HEIs from public funding is not only justified, but even preferred: it is considered a guarantee for the autonomy and self-regulation of scholars and a protection from the logic of market for research and teaching activities.

The reform of the accounting system in Italian HE carried institutional complexity: in such a context, coercive pressures do not necessarily bring to procedural compliance or mechanical processes of implementation. When multiple institutional logics exist and compete for attention, members of the organization may work as institutional entrepreneurs supporting the creation of institutions that they deemed to be appropriate and aligned with their interests (Dacin, Goodstein \& Scott, 2002) or may oppose new logics that they consider unsuitable. These actors are not passive: they perceive the meanings of institutions and infuse their actions with meaning based upon their perceptions. Accounting change is prompted by external stimuli, but, once the change is prompted, the outcomes of change are explained by the dynamics of intra-organisational conditions (Liguori \& Steccolini, 2012). Thus, change is not simply a matter of adjustment to external pressures (Greenwood \& Hinings, 1988; Ter Bogt and Van Helden, 2000): it is also shaped by intra-organisational conditions (Pettigrew, 1985). External factors act as constraints and stimuli to which responses must be worked out by the members of an organisation: organizations may respond differently to the same environmental pressures, thereby leading to different outcomes (Ezzamel, Robson \& Stapleton, 2012). 
With reference to Italian universities, two factors influenced the reactions to the introduction of accrual accounting in Italian HE (Agasisti, Catalano \& Erbacci, 2018): the level of resistance to change and the organizational practices implemented to weaken resistances. Three main factors boosted resistance: poor understanding of the motivations suggesting the need of a reform, lack of familiarity with the new accounting system and low propension to change well-established procedures. On the other hand, awareness of the path undertaken in adopting accrual accounting at all levels of the organization and intense involvement of structures in the process of change worked in favour of a more effective adoption of the new system.

According to Gigli, Mariano \& Trivellato (2018). merely formal adherence to the new reform in Italian HE is the consequence of several factors at different stages of the process of accounting change. In the early stage of framework definition, the disconnection of the new accounting standards with actual practices and the ambiguity of goals in the budgeting rules are considered to contribute to decoupling. In the phase of data collection, the habitual practices of cash accounting hinder the process of change. In the implementation phase, lack of accounting skills is considered the principal obstacle to effective adoption of the new system.

These analyses focus on the reasons for resistance to change and for decoupling (Agasisti, Catalano, Di Carlo \& Erbacci, 2015; Gigli et al. 2018); the adoption of different accounting choices by different universities is attributed to the lack of precision of the rules on budgeting and research projects (Gigli et al., 2018). It is reasonable to expect, however, that the consequences of resistance to change extend also to other aspects of the accounting practices and procedures. In particular, two traits of the reform were particularly disrupting and therefore likely to be subject to resistance: first, the measurement of universities' financial performance through the introduction of the income statement, which represented the emblem of universities' commercialization and of the abandonment of the Humboldtian model. Second, the shift from department-level to university-level budgets and reports: the centralization of administrative practices was perceived as a serious threat for the autonomy of departments and research groups. The two pillars of HEIs' identity seemed under attack: on one hand, the introduction of the 'Statement of Financial Performance' changes the institutions' self-perception, insinuating the assimilation to firms. On the other hand, the centralization of administrative practices deconstructs rooted procedures and internal power relationships, thus threatening the autonomy in research and teaching activities. Our analysis investigates how this way of perceiving the accounting change influenced the comparability and transparency of financial information.

\section{Hybridization of Italian HEIs and the Role of the Accounting Reform}

Italian Higher Education (HE) system has undergone deep reforms in the last ten years. Changes regard almost all aspects of universities' life: the funding system, the composition and the functions of institutional bodies, the procedure for the recruitment of academics, the process of performance audit, the structure of the degree programs and the accounting system. Through the reform, the regulator has grafted elements of the managerial logic into Italian HEIs. Following a broader international trend, the Italian ministry of HE (MIUR) elicited competition among universities by substituting the input-based funding system with a new one based on performances. The purpose was the achievement of specific sector-wide objectives: the improvement of researchers' productivity and of the quality of teaching, as well as the internationalization of Italian HEIs.

Before the reform (law 240/2010). the Ministry of university and research (MIUR) did not interfere in the definition of universities' goals, which were outlined by academic guilds that were the real coordinating mechanism at both the institutional and the systemic level. The Ministry uses now three important levers to influence public universities' strategies: (i) the performance-based funding system, (ii) the definition of sector-wide goals that universities have to pursue, and (iii) the assessment of the performance through a national agency. Intensified competition stimulates the adoption of managerial control systems in HEIs, since the assessment of each department's and of each scholar's contribution to the general performance is becoming increasingly important. Similar trends are observable in other countries, although differences are recognisable in the governance of the HES (Capano, 2011).

The new context of increased competition and the imperative to appoint in the HEIs' boards persons with recognized managerial skills not belonging to the academic class, fostered the perception of the reform as a move toward marketisation of universities. Since centuries, the great autonomy traditionally granted to Italian HEIs in the fulfilment of their mission encouraged the spread of self-referential logics and lack of accountability that, in the end, led to their delegitimization. The Italian society recognized the necessity of a reform of the whole sector, but a strong reaction from HEIs was expectable: the new logic enforced by the ministry was perceived as opposite to the self-perpetuating logics of HEIs. Enforcing the adoption of a business-like accounting system questioned the perceived identity and the moral legitimacy of universities. The reaction was 
showy: a great number of yellow flags with the slogan 'for public schools and universities' hung for many months from Italian universities' windows to remark the perils of HE marketization. The new accounting system was recognized within $\mathrm{HE}$ as the principal mean to disseminate the new institutional logics fitting with a new, business-like, university: thus, the accrual-based accounting system was the natural candidate to become the arena of this conflict.

The introduction of these mechanisms responds to a generalized request raised by the Italian civil society for better performing HE. In the meanwhile, the government's support to universities has fallen in Italy by $20 \%$ at real monetary value (EUA, 2014 p.16) from 2008 to 2014. In such a context, financial sustainability has become an imperative. As Guthrie (1993) and Parker \& Guthrie (1993) projected in the early 1990s, 'financial discipline' and 'efficiency' have become central to public sector accountability: universities are now expected to pursue increased incomes while lowering costs. The NPM philosophy of cost containment, outcome maximization and accountability for results has extended to HE (Mussari \& Sostero, 2014).

The grafting of private businesses' values and rules into public universities has initiated a process of hybridization. A first dimension of hybridity refers to the governance of HEIs: the reform has attributed more decisional power to the rector and the board, aiming at reinforcing their role of guidance. The rector has now function of legal representation, strategy definition and coordination of scientific and didactic activities. The reform has attributed a pre-eminently advisory role to the senate, i.e. the body of representatives of scholars, administrative staff and students. It is now prerogative of the board to approve the budget for revenues, expenses and investments, as well as the choice to offer new degrees or cancel the existing ones. It is noteworthy that, in accordance with the reform, persons with 'recognized managerial skills' have to be appointed in the board: three of the eleven members of the board are appointed in representation of external stakeholders. In 2015, 57\% of these 'external members' of the board of Italian universities came from corporations and consultancy firms. Due to their background, they promote a new culture and new values in HEIs. Efficiency, effectiveness, merit and financial sustainability have become core values beside and sometimes against the traditional values of $\mathrm{HE}$ accessibility and research autonomy.

The accounting system was used as vehicle for the introduction of these new values: the shift to accrual accounting aims at providing information on the cost of services and activities and on the financial sustainability of the institution, thus emphasising the importance of efficiency.

The reduction of governmental funding further boosts the process of hybridization by inducing the need of diversifying revenues (Jongbloed, 2015): for-profit activities such as post-graduate courses and initiatives of technology transfer represent alternative sources of funds that may support teaching and research. Lastly, the above mentioned introduction of performance measurement for the allocation of a share of the governmental funds has stimulated competition among and within universities, resulting in a so far unknown pressure on scholars.

The accounting system that results from the reform is also hybrid. Before 2010, Italian universities could choose any kind of accounting system: except for two, all of them adopted commitment accounting. According to the law n. 240/2010, from 2016 all Italian universities had to introduce accrual accounting and double-entry bookkeeping. Decrees 18/2012 and 19/2014 defined the guidelines for implementing the new system, the accounting standards and the layout of universities' financial statements. Notwithstanding the shift to accruals, the law assigns an authorizing function to the budget: responsibility centres are allowed to use resources within predetermined limits that depend on a conservative evaluation of prospective revenues. Rather than authorizing cash expenditures, accrual-based budgets authorize expenses within a programmed level of incomes. Moreover, the budget specifies the destination of resources: in this sense, it sets out the efficiency conditions that a university must pursue to ensure its own financial sustainability. However, an authorising budget may also produce contradictory effects by stimulating the use of resources up until the predetermined limit: using less resources than authorized, indeed, may be interpreted as an initial overestimation of the resources given to a responsibility centre to achieve its goals, thus suggesting cuts of budget allocations in the following period. This induces organizational units to use all resources authorized in the budget, regardless of the achievement of any real benefit. As a matter of fact, an authorizing budget defines the minimal conditions of efficiency accepted by the organization to preserve its financial sustainability, but it doesn't allow to avoid any possible waste of resources within the predetermined limits.

The hybridity of the accounting system derives also from the heterogeneity of universities' activities. Higher education is characterized by the coexistence of incomes from non-exchange transactions (budget allocations from the Ministry). tariffs (student fees) and incomes from market transactions (commissioned research, 
publishing activities...): the accounting system serves all the different activities, regardless of their public or for-profit nature.

The reform requires a substantial change of the accounting techniques as well as a restructuring of the accounting processes. In the past, schools and departments were financially autonomous organizational units: each one adopted its own budget and approved its own financial statements. The reform has introduced an entity-wide budgetary and financial reporting systems, i.e. representing the financial position and performance of the institution as a whole. In terms of budgeting and administrative procedures, this is a major break with the past that implies an organizational and cultural change towards a more important role of universities' central administrative office in coordinating the financial management of the institutions.

Table 1 summarises the effects of the recent reform on the accounting system of Italian universities.

Table 1. Main aspects of the accounting reform in Italian HE

\begin{tabular}{|c|c|c|}
\hline & Before the reform & After the reform \\
\hline $\begin{array}{l}\text { Basis of the } \\
\text { accounting system }\end{array}$ & $\begin{array}{l}\text { - No mandatory system; cameralistic } \\
\text { accounting largely dominant }\end{array}$ & - $\quad$ Accrual \\
\hline Role of the budget & - Authorising: to prevent overspending & $\begin{array}{l}\text { - Authorising: to prevent losses that would affect the value } \\
\text { of net assets }\end{array}$ \\
\hline $\begin{array}{l}\text { Time span of the } \\
\text { budget }\end{array}$ & - $\quad$ One year & - $\quad$ Three years \\
\hline $\begin{array}{l}\text { Wideness of the } \\
\text { budget }\end{array}$ & $\begin{array}{l}\text { - Decentralized: many responsibility } \\
\text { centres with financial autonomy }\end{array}$ & - $\quad$ Centralized: one entity-wide budget \\
\hline $\begin{array}{l}\text { Structure of the } \\
\text { budget }\end{array}$ & $\begin{array}{l}\text { - Each unit adopts one budget including } \\
\text { operating as well as investing and financing } \\
\text { expenditures }\end{array}$ & $\begin{array}{l}\text { The budget of the institution is made up of two major } \\
\text { documents: the budget of incomes and expenses and the budget } \\
\text { of the investments }\end{array}$ \\
\hline $\begin{array}{lr}\text { Mechanism } & \text { for } \\
\text { pursuing } & \text { financial } \\
\text { sustainability }\end{array}$ & $\begin{array}{l}\text { - Budgetary spending had to be covered } \\
\text { with budgetary appropriations and previous } \\
\text { years' accumulated surplus. }\end{array}$ & $\begin{array}{l}\text { - Programmed expenses (including depreciation) should } \\
\text { not exceed expected incomes, otherwise the unbalance must be } \\
\text { covered with previous years' unrestricted retained margins. } \\
\text { - Future investments are excluded from the balancing of } \\
\text { incomes with expenses. }\end{array}$ \\
\hline Financial reporting & No mandatory structure & $\begin{array}{l}\text { - } 3 \text { main documents with mandatory layout: Balance Sheet, } \\
\text { Statement of Financial Performance, Cash Flow Statement }\end{array}$ \\
\hline
\end{tabular}

PSAA is expected to foster the shift from a bureaucratic to a managerial approach. However, the risk to observe the opposite process is not remote: the existing organizational culture might tame the accounting system, thus depriving the latter of its potential for change.

\section{Methodology}

The paper is part of a broader research project, which aims to identify obstacles in the shift to the new accounting regime in public universities. The project deals with the accounting treatment of specific aspects of universities' activity (e.g. libraries, research projects, student fees...). the composition of the opening financial position, the analysis of the financial performances and the use of financial information. Since the early phases of the project, comparability and transparency of universities' financial information have proven to be problematic. Several elements suggested to start an analysis of the accounting practices in the process of implementation of the reform: the lack of experience and know-how on accrual accounting in HEIs, the lack of definition of the norms with reference to specific aspects concerning the peculiar activities of universities and the explicit opposition to the reform in large part of the academic class.

With reference to comparability and transparency of financial information, two main assumptions underlie the reform: First, the idea that common accounting rules bring to comparable financial statements; second, that accrual accounting enhances transparency by enabling to assess the financial sustainability and to give a more comprehensive representation of the financial position. However, the reform brought institutional complexity and prompted strong reactions: the presence, within the organizations, of different groups of interest having different power and capacity of action could have led to divergent accounting procedures. In this sense, making these dynamics emerge and revealing their impact on the accounting choices contributes to the understanding of the factors that hinder the fulfillment of the goals of the reform. 
The research was conducted in strict collaboration with university managers in charge for the shift to the new accounting system, or with their associates: managers involved were aware of the aim of the project and considered that their contribution might have helped to recognize and disseminate the best accounting practices. 14 universities were involved. All the HEIs had already published annual reports according to the new standards or were close to do it for the first time. At the time when the research project started (January 2015). the shift to accrual-based accounting system was at embryonal state - or not initiated at all - in most Italian universities: thus, the case studies considered here represent almost the whole population of universities in an advanced stage of the transaction to the new accounting system at that time.

The research was organized in 2 phases. The first phase developed in 2015, when the research team organized semi-structured interviews to detect the major obstacles to transparency and comparability. The interviews were preceded by a preliminary analysis of the norms and of the accounting standards for HEIs. Furthermore, the research team examined the financial statements of some universities that introduced the accrual accounting system before the deadline imposed by the reform. This preliminary analysis aimed at identifying the most controversial aspects and the main obstacles to comparability. Thus, interviews focused on the accounting treatments used for specific transactions: student fees, research projects, policies of depreciation, accounting for equity reserves, estimation of libraries and collections, provisions for risks. Respondents were requested to explain the accounting treatment adopted and to express his/her personal view of the reasons that led to that choice. An excerpt from each interview was transcribed in a common layout in order to facilitate comparisons. The results of the interviews were presented to all the administrative managers in a final workshop in November 2015. Strictly speaking, this step cannot be considered as an integral part of the research: the purpose was to share the results of the analysis, to compare and discuss the different practices as well as their consequences on the transparency and comparability of financial information.

A second phase followed in 2018: telephonic interviews were conducted with the universities that had adopted heterodox accounting practices in the early stage of implementation of the reform, in order to check if any change of the initial accounting practices occurred.

\subsection{Accruals: A Recipe for Financial Sustainability and Efficiency Improvements in HE? Evidences of a Problematic Relation}

As mentioned above, financial sustainability was a major goal of the HE accounting reform. Accrual accounting is supposed to foster it (Evans, 1995) since it takes into account future obligations arising from past decisions (e.g. retirement benefits, contingent liabilities) and the recovery of fixed assets through depreciation (HM Treasury, 1994). Although the assessment of financial sustainability is probably the most celebrated advantage of accrual accounting, some issues suggest caution in the interpretation of universities' financial performance. The interviews with the heads of administrative departments shed light on some controversial aspects that may reduce the capability of the accounting system to provide reliable, transparent and complete information. The occurrence of internal resistance to change, the lack of accrual accounting skills and the need to adopt an appropriate IT equipment are typical organizational obstacles to a proper adoption of accrual accounting (Ongaro \& Valotti, 2008).

The initial vagueness of the rules -remedied by a subsequent decree- led to different solutions for the construction of the budget (Gigli et al., 2017) that, however, did not affect the comparability and the transparency of financial results. With reference to these two declared purposed of the reform, data reveal that the main concerns stemmed from the recording of research projects and student fees: different practices developed by universities in these matters hampered comparability and transparency. Moreover, some inconsistencies of the accounting principles with the activities of universities was noticed. Evidences emerged from the interviews are presented below.

\subsubsection{Exogenous Factors Hampering the Quality of Financial Information}

As mentioned above, the introduction of the 'Statement of Financial Performance' was one of the most revolutionary aspects of the accounting reform: for the first time, universities assessed the 'result of the period' by comparing revenues and expenses instead of budgetary appropriations and budgetary spending. In the new system, also the budget is also prepared on accrual basis. The rhetoric of accrual accounting, amplified by the political debate on inefficiency of the Italian HE system, suggests that the result of the period in universities can be assimilated to the net income of corporations. As a consequence, the addressees of financial information tend to interpret this margin as a measure of economic efficiency. However, some issues suggest caution in this respect.

The first aspect is inherent to the funding of Italian universities: as in many other European countries, their 
revenues arise mostly from non-exchange transactions. Transfers from the Department of Higher Education (Ministry of Instruction, University and Research: MIUR) and other public institutions account for about $65 \%$ of universities' revenues. Other sources of funds are student fees and research grants from private or public entities. Transfers from the ministry and other public institutions are general operating supporting grants: they are recorded as non-restricted revenues of the period at the grant confirmation. Transfers refer to a specific financial period (e.g.: ministry funds for 2019) and therefore are fully attributed to the year of assignment. According to IPSAS 23, transfers from MIUR are "revenues from non-exchange transactions". The destination of non-restricted revenues depends on each university's choice: mostly, non-restricted resources cover operating expenses of the period. No matching problems arise. In some circumstances, however, the matching of revenues with expenses is not respected, thus diminishing the quality of financial information.

This problem occurs whenever the board authorizes plurennial projects: typically, research projects. These activities are not funded with restricted grants (e.g. competitive research grants) and are not associable to a specific non-restricted revenue. The commissioning body of the project is the university itself. The lack of a direct correlation between the expenses incurred in the long-term project and a specific revenue inhibits the identification of a revenue to defer. Thus, the matching between expenses and revenues is not guaranteed: non-restricted grants are recorded in the period, while expenses that have been authorized are charged in the period of incurrence.

This accounting treatment delegitimizes the result of the period as efficiency measure, thus hindering the understand ability - and the transparency - of accounting information. The bottom line of the statement of financial performance includes, together with margins on competitive research projects and on commercial activities, the value of transfers not used in the period that are available for future activities. When expenses covered by non-restricted revenues are deferred to future years, universities overestimate their financial performance. Symmetrically, the postponement of expenses will reduce future periods' result: it might even originate a net loss that, however, would connote neither inefficiency nor lack of financial sustainability. The mismatch between revenues and expenses breaks the equivalence between positive (negative) results and economic efficiency (inefficiency). The effect of the mismatch might be even more disrupting: the beneficiaries of the resources for a plurennial research project may postpone some of the research activities and the correlated expenses due to their inability to respect the research program, thus contributing to further augment the result of the period. In this case, the final result - or at least part of it - far from being a signal of efficiency, is attributable to ineffectiveness.

The problem is nothing but irrelevant. All universities involved in the project noticed it; one reported the effects in the introductory notes to the financial statements:

"Let's consider the nature of this result. Only if we analyse its determinants, we can assess the financial performance of our university. It emerges that for $€ 2.6$ millions the result of the period is attributable to the postponement of expenses already authorized in the budget. Activities financed with resources of the period have been procrastinated and will originate expenses in future periods: this reflects an implicit ineffectiveness that we must try to eliminate. As a whole, our equity includes $€ 9,2$ millions of resources that are waiting for being used."

A second issue that suggests caution in interpreting the result of the period as a measure of financial sustainability and that hinders transparency of financial information is the coverage of depreciation. This expense was simply not considered in the previous accounting system; after the reform, according to the budgetary accounting system, revenues must cover all expenses, included depreciation. Considered that the value of universities' properties is often huge, the resulting depreciation may threaten future financial sustainability. The accounting standards issued after the reform consider this problem; in particular, with reference to the non-current assets already available at the time of the shift to accrual accounting, the standard setter allows to neutralize the effect of depreciation by recording a revenue which is created by reducing an equity reserve. Thus, rather than showing a loss, universities hide it by transmuting equity into a revenue: the negative effect on equity remains, but there is no evidence of the incapacity, for the university, to fully recover the expenses and, in particular, to recover the value of the fixed assets in the long period. Also this accounting practice distorts the result of the period and reduces transparency; in this case, the distortion depends on a specific accounting choice developed by the standard setter. It is important to note that among our sample there is one University that didn't follow this specific accounting choice, as it started with accrual accounting before the issue of the law.

\subsubsection{Endogenous Obstacles to Comparability and Transparency}

In the early stage of implementation of the reform, lack of comparability of the financial performance was 
originated by different depreciation rates used by HEIs for the same classes of non-current assets, as well as by the accounting treatment of specific items such as libraries, research grants and student fees. The last two issues arouse particular interest.

Research grants are the third most important stream of revenues for Italian universities. Grants pertain to specific research projects and aim at the coverage of expenses attributable to the latter. The central administrations of HEIs retain part of the research grants earned by the departments for the coverage of overhead costs that pertain to the university as a whole and are not directly associated to the research project. At the moment of the research project's approval, all these indirect expenses are already covered by other incomes in the authorizing budget: indeed, HEIs balance their budgets regardless of uncertain revenues such as prospective research grants. Thus, when a research team gets a grant, revenues increase in the budget and the part of the grant destined to the coverage of indirect expenses generates a margin. This margin should improve the result of the period of the university. Research groups, however, fear that confusing this margin within the institution's net income could result in a reallocation of the resources to other destinations, thus preventing them from using the funds to develop new research activities. The margin generated by the project could, indeed, be absorbed by losses generated in other departments or could simply be destined to other purposes in the budgetary process.

The academic staff of four HEIs encouraged the adoption of an accounting treatment aiming at eluding the reallocation of resources obtained with research activities: in order to keep control over the resources, the margins from research were deferred to the following periods by assigning them to research projects specifically created for this purpose. In these HEIs, the same treatment was extended to the margins from for-profit activities promoted by the academic staff, e.g. research funded by corporations. As a matter of fact, this conduct produced the underestimation of the financial results of some universities. Again, part of the institution's income is not reported in the financial period: this does not depend on the inadequacy of the accounting standards, but rather on unwritten intra-organizational rules that give priority to the departments' (or research group's) goals rather than to the institution as a whole.

Another obstacle to comparability and transparency was caused, in two universities, by the recording of student fees. In the perspective of accrual accounting, student fees represent revenues that have to be fully recorded at the date of students' enrolment. Due to the lack of coincidence, in the Italian HE system, between the financial year (f.y.) and the academic year (a.y.). the recognition of these revenues is problematic. Universities collect student fees for a single a.y. in two tranches: the first one within the end of f.y. 1 and the second one within the first half of f.y. 2. The value of the second tranche is unknown at the date of student's enrolment: it is calculated later, taking into consideration each student's family income. Thus, the second tranche may even be negative, resulting into a partial reimbursement of the first one. As a matter of fact, the value of each tranche is not proportional to the service delivered in each of the two financial periods.

Due to the difficulty to apportion this revenue in the two financial periods that overlap the academic year, two universities involved in the project adopted a cash-based principle and recorded student fees only when the financial transaction actually occurred. The adoption of this method was attributable to a temporary lack of adequate accounting skills in the early years of the adoption of the reform: this practice simplified the recording of student fees but reduced the quality of accounting information and undermined the correct evaluation of the result of the period. As a matter of fact, the final result of the period was not representative of the entity's financial performance.

According to the financial manager of one of the universities, "this problem is not due to ambiguities in the accounting theory, but rather to practical obstacles in the implementation of the reform at a reasonable cost. Thus, the full implementation of the accounting change towards AA should also consider such practical limitations'.

\section{Discussion}

Interviews showed that the financial result of the period misrepresented the performance of the universities and that notwithstanding all universities acted within a common regulatory framework, comparability was not guaranteed. In other words, the most celebrated advantage of accrual accounting -i.e. the measurement of economic efficiency and sustainability of the university as a whole- generated ambiguity and opacity in the financial statements.

Ccomparability and transparency of financial information are influenced by an exogenous factor (i.e. the adequacy of the new accounting rules) as well as by endogenous obstacles, i.e. the organizations' capability and determination to implement the change. Ambiguous accounting rules, to some extent also unfitting with the activities of the organization, hindered transparency; but even suitable accounting rules enhance the quality of 
accounting information to the extent that organizations involved in the change were able and interested to implement them correctly.

With reference to the inadequacy of accounting standards, it can be assumed that the mismatch between revenues and expenses discussed in the previous section concerns all public institutions that finance pluriannual projects through revenues from non-exchange transactions: Barton (2004, p. 284) emphasizes this lack of direct matching for most of a government's activities (Christiaens \& Rommel, 2008). A possible solution to this ambiguity might be the introduction, in the notes, of an adjunctive statement to split the different determinants of the result of the period. When the budget is prepared on accrual-basis, expenses are authorized to a certain extent, thus defining minimal conditions of efficiency; the statement of financial performance allows then to verify whether programmed conditions of efficiency were respected. Thus, the new statement could explain the deviations from the budget. Since revenues and expenses must balance in the authorizing budget, respecting all budgetary forecasts would necessarily lead to break-even. Therefore, universities can record positive financial results only if one or more of the following conditions occur: a) actual revenues exceed budgeted revenues, not resulting into an equivalent increase of expenses; b) actual expenses are lower than budgeted, thanks to efficiency conditions; c) some expenses already authorised in the budget were postponed to future periods, thus deferring their effect on the financial result. Opposite conditions would cause a loss. The three situations described here reflect different signals: the first case (budgeted revenues lower than actual) reveals that the budget was conservative or that the university was effective in attracting financial resources; the second situation shows that efficiency conditions exceeded expectations; the last situation, that depends on the postponement of expenses, may instead hide the inability to perform all programmed activities (ineffectiveness).

In Table 2 it is possible to see a summary of the findings of our research.

Table 2. Information on Universities

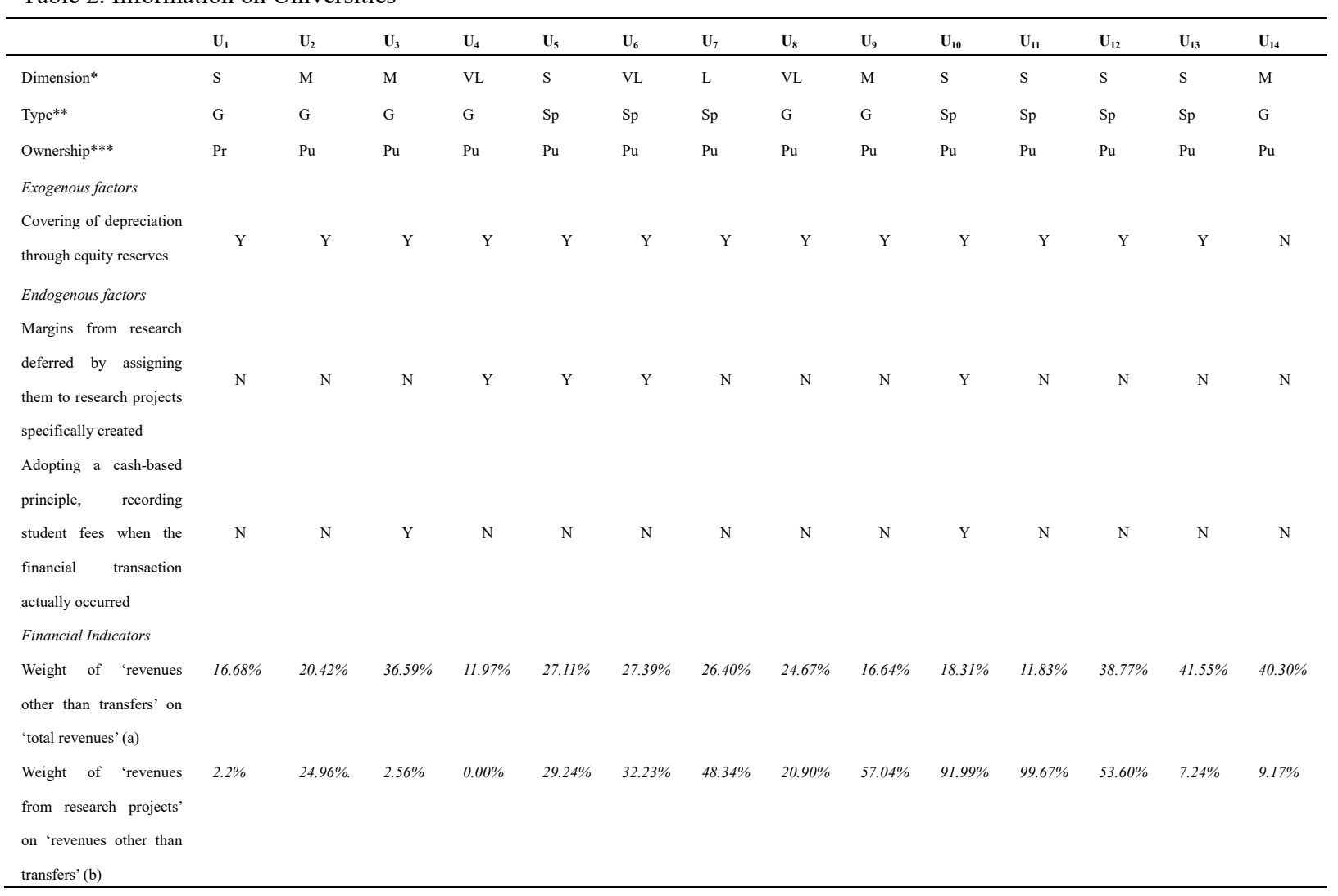

Legenda: * $\mathrm{S}=$ Small $(\mathrm{x}<10.000$ students $) ; \mathrm{M}=$ Medium $(10.000<\mathrm{x}<20.000$ students $) ; \mathrm{L}=$ Large $(20.000<\mathrm{x}<40.000$ students $)$ VL $=$ Very Large $(\mathrm{x}>40.000$ students $) ; * \mathrm{G}=$ Generalistic; $\mathrm{Sp}=$ Specialized; *** $\mathrm{Pu}=$ Public; $\mathrm{Pr}=$ Private

The second issue - i.e. the misrepresentation of the result of the period due to the virtual coverage of depreciation through the reduction of equity - depends on local accounting standards: the adoption of international public sector accounting standards (IPSAS) would allow to avoid similar unorthodox praxis that distorts the essence of 
accrual-based financial reporting.

The cases analyzed here permitted also to notice that organizations, although sharing a common regulatory framework, implemented different accounting practices. However, the two issues introduced above - namely, the deferral of margins on research and the recognition of student fees - differ in several respects.

The deferral of the margins on research projects and their assignment to new projects reflected the scholars' determination to maintain control over the financial resources they were capable to attract. This was simply the norm before the reform: the departments were guaranteed administrative and financial autonomy, and research groups had complete control over the resources they were capable to attract. The academic staff perceived the new accounting system as a threat to their prerogatives: including the margins from their research projects in the general result of the university was considered an interference in their autonomy and, as a matter of fact, a reduction of their power. When accounting change is assimilated to an identity change, it stems existential problems that can lead to resistance: the attribution of the margins to new research projects under the control of the same research teams seemed the most suitable solution in order to keep previous habits unchanged. The interviewees revealed that the new accounting treatment was endorsed to avoid reactions from the academic staff. Institutional complexity induced by the introduction of new values through the accounting reform stimulated this reaction: since scholars and researchers perceived that the new accounting system threatened their interests, some universities adapted it to meet the needs of this group, regardless of the consequent misrepresentation of the financial result of the institution. This situation did not depend necessarily on explicit pressures exerted by academics. According to respondents, in two universities $\left(\mathrm{U}_{4}\right.$ and $\left.\mathrm{U}_{6}\right)$ the awareness of the considerable impact that the new accounting regime would have had within the organization induced the central administration to adapt the rules in order to maintain the existing logics. In the other two universities $\left(U_{5}\right.$ and $\left.U_{10}\right)$. instead, the practice of deferring the margins on research projects was introduced on request of the academic staff in the departments.

Indeed, four HEIs adapted the accounting system to the interests of the academic staff: supposedly, universities with deeply rooted public identity, i.e strongly contrary to the commercial logic, and where the research teams had more power. In order to verify this assumption, we used two financial ratios aiming at identifying (a) the HEIs highly dependent on transfers from the government and (b) the HEIs where research teams reasonably had a dominant role. The first ratio measures the weight of 'revenues other than transfers' on 'total revenues': the lower the ratio, the lower the inclination of the university to competition and, more generally, to the market logic. The second ratio, aiming at assessing the importance of research activities, compares 'revenues from research projects' with 'revenues other than transfers': a high ratio denotes strong attention of the academic staff towards the research activity and, therefore, a greater interest of the research teams to control the financial resources related to this activity. However, this analysis doesn't provide clear signals. In particular, two universities are clearly oriented to competition and less dependent on transfers from the ministry (i.e.: market logic). but their proceeds from research are slightly below average; one university has strong research vocation but also high dependence on transfers; the fourth HEI has high dependence from the ministry but low incidence of revenues from research projects. In Table 3 has been reported some descriptive statistics on the results on these indicators.

Table 3. Financial indicators, descriptive statistics

\begin{tabular}{lllll}
\hline & Mean & Median & Dev Std & Variance \\
\hline Indicator (a) & $25,62 \%$ & $25,54 \%$ & 0,099532 & 0,009907 \\
Indicator (b) & $34,94 \%$ & $29,24 \%$ & 0,335167 & 0,112337 \\
\hline
\end{tabular}

All other universities considered here had to cope with the problem of margins from research, but the determination to comply with the new accounting rules prevailed: all margins from research projects participate to the financial result of the institution. The allocation of earnings to future activities was then organized according to internal rules and procedures. This profiles the existence of an internal conflict between two main cultures already existing when the reform was introduced: the bureaucratic culture of the administrative staff inspired to compliance with the norms, and the clan culture of the academics shaped by traditional values of autonomy, self-management and loyalty to the group. Although the implementation of the accounting reform should have been a prerogative of the administrative staff, in some universities academics were able to influence some choices.

On closer inspection, the effect of the reform on organizational rules did not depend on the shift from cash-basis 
to accrual accounting. Rather, it was due to the centralization of administrative activities enforced by the reform: the emphasis placed by the legislator on the nicety of the university's budget implied that each department had to contribute to the organization's financial performance. After some years, the accounting treatment of this issue has been harmonized: although the measure of the withdrawal of resources for the coverage of overheads depends on each university's internal decisions, nowadays all universities reassign the net margins from research projects to the research team that procured the funding. However, the shift of resources to the new project is performed through a budget variation: with reference to financial reporting, the only effect is a restriction on part of the university's financial result, since it has to be allocated to new projects of the research teams that originally received the grants. The adoption of a common solution by all HEIs - which of course enhances the comparability of HEIs' financial statements - was favoured by CINECA, the supplier of the software for the new accounting system. CINECA is a non-profit consortium that includes 70 Italian universities.

The other problem concerning comparability, i.e. the cash-basis recognition of student fees, was neither due to any unfitness of the new accounting rules to meet the information needs of universities, nor to the perception of a threat for the interest of any particular group: rather, it was caused by difficulties of the administrative offices of two universities in developing specific procedures compliant with the norm. These procedures were difficult to implement because of the need to know each student's family incomes early enough to calculate the total fee and distribute it in the two financial periods of the academic year. As mentioned above, because of this technical problem, two universities recorded student fees on a cash basis within the framework of an accrual-based system in the early years of implementation of the accounting reform: this produced the only effect of misrepresenting the result of the period but did not provoke any reaction within the organization. Academics didn't even recognize the problem, which was merely under the supervision of the administrative staff. Both universities solved the problem in the subsequent years: this shows that the culture of non-academic staff is generally oriented to compliance with the rules. In these circumstances, adherence to the norms found no resistances, since the change in the rules was not perceived as a limitation to the autonomy of research and teaching that HEIs aimed to preserve.

\section{Conclusions}

The adoption of public sector accrual accounting is often associated to the need of measuring efficiency and ensuring financial sustainability. In Italy, the shift to accrual-based accounting in HE aimed at enhancing universities' financial sustainability, and at improving the comparability and the transparency of financial information. However, the analysis conducted on 14 Italian HEIs shows that the introduction of the new rules didn't automatically guarantee these achievements. The analysis of accounting practices and the interviews to the administrative managers revealed that two different sets of reasons hindered the accomplishment of the reform objectives: exogenous factors (i.e. accounting rules inducing misrepresentations of the financial performance) and endogenous factors such as resistance to change and scarce competencies of the administrative staff on accrual accounting.

Exogenous factors refer to international accounting standards (IPSAS) as well as to local norms: both produce an alteration of the result of the period, thus giving rise to misinterpretations of universities' financial performance. This distortion is ascribable, in particular, to the mismatch of revenues and expenses in long-term projects funded by proceeds from non-exchange transactions and to inappropriate accounting choices adopted in Italy for the coverage of depreciation. Reasonably, the first problem affects all public institutions engaged in long term projects. We suggest that universities should enclose an additional statement on deviations from the budget, in order to provide a clearer understanding of their financial performance.

While the exogenous factors affect the quality and understand ability (i.e. transparency). endogenous factors influence also the comparability of financial information. The transition to entity-level, business-like financial management marked a radical change for Italian universities and induced the coexistence of conflicting values in the organizations. However, the overlapping of rules taken from the private sector (e.g. accruals) with traditional rules from the public sector (e.g. authorised budget) induced universities to adopt unorthodox accounting treatments based on custom-made internal rules. Moreover, the reform left some aspects of the new accounting setting quite undefined. In a situation of institutional complexity, the vagueness or even the incongruence of the normative frame gave rise to heterogeneity rather than to institutional homogenization (Beckert, 2010). In the phase of reform implementation, the lack of specificity provided universities with relatively more discretion in their efforts to alleviate the tensions of complexity (Greenwood et al., 2011). Our analysis has evidenced that lack of comparability depended on specific choices adopted by each university, aiming at adapting the new accounting system to pre-existing unexpressed rules and power relations. Indeed, this problem cannot be ascribed to the characteristics of the accounting system itself: rather, it depended on how the academic staff 
reacted to the reform of the accounting system. This group considered the commercial logic of the new accounting system unrelated to the context of universities and - even more important - contrary to its own interests: thus, in some universities the academic staff influenced the process of accounting change trying to keep existing logics unchanged. This group of interest stimulated the use of unorthodox accounting solutions to maintain its prerogatives in the management of financial resources.

The risk of organizational resistance to change had to be considered, first and foremost by the legislator: lack of specificity in the norms weaken the possibility of cultural change promoted with the reform of the accounting system. However, the subsequent analysis performed in 2018 reveals that the universities could remove these obstacles. Two factors contributed to this improvement: the setting of more detailed accounting standards and the dissemination of best practices. The fact that most universities have the same IT solution provider for financial management is by no means irrelevant. After the early stage of implementation of the reform, the supplier of the IT solution fostered a common solution through the organization of workshops dedicated to the administrative staff of HEIs. The new procedures comply with the norms while safeguarding the possibility, for each university, to meet the needs of the academic staff. The role of the providers of IT services in the spreading of accounting practices that can favour the acceptance of accounting change might be further explored in successive research.

\section{References}

Agasisti, T., \& Catalano, G. (2013). Debate: innovation in the Italian public higher education system: introducing accrual accounting. Public Money \& Management, 33(7), 92-94. https://doi.org/10.1080/09540962.2013.763414

Agasisti, T., Catalano, G., \& Erbacci, A. (2018). How Resistance to Change Affects the Implementation of Accrual Accounting in Italian Public Universities: A Comparative Case Study. International Journal of Public Administration, 41(12), 946-956. https://doi.org/10.1080/01900692.2017.1301469

Agasisti, T., Catalano, G., Di Carlo, F., \& Erbacci, A. (2015). Accrual accounting in Italian universities: a technical perspective. International Journal of Public Sector Management. https://doi.org/10.1108/IJPSM-02-2015-0026

Barton, A. D. (1999a). Public and Private Sector Accounting-The Non-identical Twins. Australian Accounting Review, 9(18), 22-31. https://doi.org/10.1111/j.1835-2561.1999.tb00105.x

Barton, A. D. (1999b). A trusteeship theory of accounting for natural capital assets. Abacus, 35(2), 207-222. https://doi.org/10.1111/1467-6281.00041

Barton, A. (2004). How to Profit from Defence: A Study in the Misapplication of Business Accounting to the Public Sector in Australia. Financial Accountability \& Management, 20(3), 281-304. https://doi.org/10.1111/j.0267-4424.2004.00388.x

Barton, A. D. (2002). Public-Sector Accounting: A Common Reporting Framework? A Rejoinder. Australian Accounting Review, 12(28), 41-49. https://doi.org/10.1111/j.1835-2561.2003.tb00210.x

Benito, B., Brusca, I., \& Montesinos, V. (2007). The harmonization of government financial information systems: the role of the IPSASs. International Review of Administrative Sciences, 73(2), 293-317. https://doi.org/10.1177/0020852307078424

Blöndal, J. R. (2003). Accrual Accounting and Budgeting: Key Issues and Recent Developments. OECD Journal on Budgeting, 3(1), 43-59. https://doi.org/10.1787/budget-v3-art4-en

Bowerman, M., \& Humphrey, C. (2001). Should Non-Financial Performance Information be Audited? The Case of Public Service Agreements in UK Government. Australian Accounting Review, 11(25), 35-43. https://doi.org/10.1111/j.1835-2561.2002.tb00388.x

Broadbent, J., \& Guthrie, J. (2008). Public sector to public services: 20 years of 'contextual' accounting research. $\begin{array}{llll}\text { Accounting, Auditing \& } \quad \& \quad \text { Accountability } & \text { Journal, } 29-169 .\end{array}$ https://doi.org/10.1108/09513570810854383

Bromwich, M., \& Lapsley, I. (1997). Decentralisation and management accounting in central government: recycling old ideas? Financial Accountability \& Management, 13(2), 181-201. https://doi.org/10.1111/1468-0408.00033

Brusca, I., \& Martínez, J. C. (2016). Adopting international public sector accounting standards: A challenge for modernizing and harmonizing public sector accounting. International Review of Administrative Sciences, 82(4), 724-744. https://doi.org/10.1177/0020852315600232 
Caccia, L., \& Steccolini, I. (2006). Accounting change in Italian local governments: what's beyond managerial fashion? Critical Perspectives on Accounting, 17(2), 154-174. https://doi.org/10.1016/j.cpa.2003.05.004

Capano, G., \& Regini, M. (2015) Come cambia la governance. Università italiane ed europee a confronto, Fondazione CRUI. https://doi.org/10.1057/978-1-137-54817-7

Caperchione, E., \& Lapsley, I. (2011). Making comparisons in government accounting. Financial Accountability \& Management, 27(2), 103-106. https://doi.org/10.1111/j.1468-0408.2011.00518.x

Carlin, T. M. (2005). Debating the impact of accrual accounting and reporting in the public sector. Financial Accountability \& Management, 21(3), 309-336. https://doi.org/10.1111/j.0267-4424.2005.00223.x

Carnegie, G. D., \& West, B. P. (2003). How well does accrual accounting fit the public sector?, Australian Journal of Public Administration, 37(2), 139-165. https://doi.org/10.1111/1467-8497.00327

Carnegie, G. D., \& Wolnizer, P. W. (1996). Enabling accountability in museum, Accounting, Auditing \& Accountability Journal, 9(5), 84-99. https://doi.org/10.1108/09513579610151962

Carnegie, G., \& Wolnizer, P. (1999). Unravelling the rhetoric about the financial reporting of public collections as assets. Australian Accounting Review, 9(17), 16-21. https://doi.org/10.1111/j.1835-2561.1999.tb00095.x

Carruthers, B., \& Espeland, W. (1991). Accounting for rationality: Double entry bookkeeping and the rhetoric of economic rationality. American Journal of Sociology, 97(1), 31-69. https://doi.org/10.1086/229739

Chenhall, R. H. (2003). Management control systems design within its organizational context: findings from contingency-based research and directions for the future. Accounting, Organizations and Society, 28(2-3), 127-168. https://doi.org/10.1016/S0361-3682(01)00027-7

Chenhall, R. H., \& Morris, D. (1986). The impact of structure, environment, and interdependence on the perceived usefulness of management accounting systems. The Accounting Review, 61(1), 16-35.

Christensen, M. (2007). What we might know (but aren't sure) about Public-Sector Accrual Accounting. Australian Accounting Review, 17(1), 51-65. https://doi.org/10.1111/j.1835-2561.2007.tb00314.x

Christiaens, J., \& De Wielemaker, E. (2003). Financial accounting reform in Flemish universities: An empirical study of the implementation. Financial Accountability \& Management, 19(2). 185-204. https://doi.org/10.1111/1468-0408.00169

Christiaens, J., \& Neyt, S. (2015). Public sector accounting and auditing in Belgium. In Public Sector Accounting and Auditing in Europe (pp. 27-41). Palgrave Macmillan, London. https://doi.org/10.1057/9781137461346_3

Christiaens, J., \& Rommel, J. (2008). Accrual accounting reforms: only for business-like (parts of) governments. Financial Accountability \& Management, 24(1), 59-75. https://doi.org/10.1111/j.1468-0408.2008.00443.x

Christopher, J. (2012). Tension between the corporate and collegial cultures of Australian public universities: The current status. Critical Perspectives on Accounting, 23(7-8), 556-571. https://doi.org/10.1016/j.cpa.2012.06.001

Da Cruz, N. F., Tavares, A. F., Marques, R. C., Jorge, S., \& De Sousa, L. (2016). Measuring local government transparency. Public Management Review, 18(6), 866-893. https://doi.org/10.1080/14719037.2015.1051572

Dacin, M. T., Goodstein, J., \& Scott, W. R. (2002). Institutional theory and institutional change: introduction to the special research forum, Academy of Management Journal, 45(1), 45-57. https://doi.org/10.5465/amj.2002.6283388

De Franco, G., Kothari, S. P., \& Verdi, R. S. (2011). The benefits of financial statement comparability. Journal of Accounting Research, 49(4), 895-931. https://doi.org/10.1111/j.1475-679X.2011.00415.x

Di Maggio, P. J., \& Powell, W. W. (1983). The iron cage revisited: institutional isomorphism and collective rationality in organizational field. American Sociologial Review, 48, 147-160. https://doi.org/10.2307/2095101

Evans, M. (1995). A Change for the Better? Accountancy, 115(February).

Ezzamel, M., Robson, K., \& Stapleton, P. (2012). The logics of budgeting: Theorization and practice variation in the educational field. Accounting, Organizations and Society, 37(5), 281-303. https://doi.org/10.1016/j.aos.2012.03.005

Ferlie, E., Musselin, C., \& Andresani, G. (2008). The Steering of Higher Education Systems: A Public 
Management Perspective. Higher Education, 56(3), 325-348. https://doi.org/10.1007/s10734-008-9125-5

Flamholtz, E. (1983). Accounting, budgeting and control systems in their organizational context: theoretical and empirical perspectives, Accounting Organizations and Society, 8(2/3), 153-169. https://doi.org/10.1016/0361-3682(83)90023-5

Geiger, D. R., \& Ittner, C. D. (1996). The influence of funding source and legislative requirements on government cost accounting practices. Accounting, Organizations and Society, 21(6), 549-567. https://doi.org/10.1016/0361-3682(96)00008-6

Gigli, S., Mariano, L., \& Trivellato, B. (2018). Assimilating accounting innovations: lessons from Italian public universities, Journal of Accounting \& Organizational Change, 4, 381-401. https://doi.org/10.1108/JAOC-10-2017-0101

Greenwood, R., Raynard, M., Kodeih, F., Micelotta, E. R., \& Lounsbury, M. (2011) Institutional Complexity and Organizational Responses. The Academy of Management Annals, 5(1), 317-371. https://doi.org/10.1080/19416520.2011.590299

Greenwood, R., \& Hinings, C. R. (1988). Organizational design types, tracks and the dynamics of strategic change. Organization studies, 9(3), 293-316. https://doi.org/10.1177/017084068800900301

Guillamón, M. D., Benito, B., \& Bastida, F. (2011). Evaluación de la deuda pública local en España. Spanish Journal of Finance and Accounting/Revista Española de Financiación y Contabilidad, 40(150), 251-285. https://doi.org/10.1080/02102412.2011.10779703

Guthrie, J. (1993). Australian public business enterprises: analysis of changing accounting, auditing and accountability regimes. Financial Accountability \& Management, 9(2), 101-114. https://doi.org/10.1111/j.1468-0408.1993.tb00102.x

Guthrie, J. (1998). Application of accrual accounting in the Australian public sector-rhetoric or reality. Financial Accountability \& Management, 14(1), 1-19. https://doi.org/10.1111/1468-0408.00047

HM Treasury. (1994). Better Accounting for the Taxpayer's Money: Resource Accounting and Budgeting in Government. A Consultation Paper.

Hyndman, N., \& Connolly, C. (2011). Accruals accounting in the public sector: A road not always taken. Management Accounting Research, 22(1), 36-45. https://doi.org/10.1016/j.mar.2010.10.008

Jongbloed, B. (2015). Universities as Hybrid Organizations. Trends, drivers and challenges for European Universities. International Studies of Management \& Organization, 45(3), 207-225. https://doi.org/10.1080/00208825.2015.1006027

Krisement, V. M. (1997). An approach for measuring the degree of comparability of financial accounting information. European Accounting Review, 6(3), 465-485.

Lapsley, I., Mussari, R., \& Paulsson, G. (2009). On the Adoption of Accrual Accounting in the Public Sector: A Self-Evident and Problematic Reform. European Accounting Review, 18(4), 719-723. https://doi.org/10.1080/09638180903334960

Liguori, M., \& Steccolini, I. (2012). Accounting change: explaining the outcomes, interpreting the process. Accounting, Auditing \& Accountability Journal. https://doi.org/10.1108/09513571211191743

MacIntosh, I. (1999). Public sector accounting standard setting in the next century. The Standard, 3.

Mathiasen, D. G. (1999). The new public management and its critics. International Public Management Journal, 2(1), 90-111. https://doi.org/10.1016/s1096-7494(00)87433-4

McGregor, W. (1999). The pivotal role of accounting concepts in the development of public sector accounting standards. Australian Accounting Review, 9(17), 3-8. https://doi.org/10.1111/j.1835-2561.1999.tb00093.x

Micallef, F., \& Peirson, G. (1997). Financial Reporting of Cultural, Heritage and Scientific and Community Collections. Australian Accounting Review, $31-37$. https://doi.org/10.1111/j.1835-2561.1997.tb00025.x

Modell, S. (2002). Institutional perspectives on cost allocations: Integration and extension. European Accounting Review, 11(4), 653-679. https://doi.org/10.1080/0963818022000000993

Mussari, R., \& Sostero, U. (2014). Il processo di cambiamento del sistema contabile nelle università: aspettative, difficoltà e contraddizioni. Azienda Pubblica, 2, 125-147. 
Neale, A., \& Pallot, J. (2001). Frontiers of Non-Financial Performance Reporting in New Zealand. Australian Accounting Review, 11(25), 27-34. https://doi.org/10.1111/j.1835-2561.2002.tb00387.x

Olsson, O., Guthrie, J., \& Humphrey, C. (1998). International Experiences with New Public Financial Management (NPFM) Reforms: New World? Small World? Better World? In O. Olsson, J. Guthrie and C. Humphrey (Eds.), Global Warning: Debating International Developments in New Public Financial Management (Cappellen Akademisk Forlag, Oslo). https://doi.org/10.1111/1468-0408.00082

Ongaro, E., \& Valotti, G. (2008). Public management reform in Italy: explaining the implementation gap. International Journal of Public Sector Management. https://doi.org/10.1108/09513550810855654

Ouchi, W. G. (1979). A conceptual framework for the design of organisational control mechanisms. Management Science, 833-848.

Pallot, J. (2003). A wider accountability? The Audit Office and New Zealand's bureaucratic revolution. Critical Perspective on Accounting, 14(1), 133-155. https://doi.org/10.1006/cpac.2001.0518

Panozzo, F. (2000). Management by decree. Paradoxes in the reform of the Italian public sector. Scandinavian journal of management, 16(4), 357-373. https://doi.org/10.1016/s0956-5221(00)00012-9

Parker L. D. (2013). Contemporary University Strategizing: The Financial Imperative, Financial Accountability \& Management, 29(1), 1-25. https://doi.org/10.1111/faam.12000

Parker, L. D., \& Guthrie, J. (1993). The Australian public sector in the 1990s: New accountability regimes in motion. Journal of International Accounting, Auditing and Taxation, 2(1), 59-81. https://doi.org/10.1016/1061-9518(93)90015-1

Paulsson, G. (2006). Accrual Accounting in the Public Sector: Experiences from the Central Government in Sweden. Financial Accountability \& Management, 22(1), 47-62. https://doi.org/10.1111/j.0267-4424.2006.00392.x

Pettigrew, A. M. (1985). Contextualist research and the study of organizational change processes. Research methods in information systems, 1, 53-78.

Pina, V., Torres, L., \& Yetano, A. (2009). Accrual accounting in EU local governments: one method, several approaches. European Accounting Review, 18(4), 765-807. https://doi.org/10.1080/09638180903118694

Pollitt, C., \& Bouckaert, G. (2004). Public Management Reform: A Comparative Analysis (2nd ed.). Boston: Oxford University Press.

Regan, E. V. (1987). Can Accrual Accounting Work in Government? Australian Society of CPA's Conference, Melbourne.

Robinson, M. (1998). Accrual Accounting and the Efficiency of the Core Public Sector. Financial Accountability \& Management, 14(1), 21-37. https://doi.org/10.1111/1468-0408.00048

Rodríguez Bolívar, M. P., Alcaide Muñoz, L., \& López Hernández, A. M. (2013). Determinants of financial transparency in government. International public management journal, 16(4). 557-602. https://doi.org/10.1080/10967494.2013.849169

Simmons, J. K. (1967). A concept of comparability in financial reporting. The accounting review, 42(4). 680-692.

Simons, R. (1995). Levers of control: how managers use innovative control systems to drive strategic renewal. Boston: Harvard Business School Press. https://doi.org/10.5465/ame.1995.9506273288

Stein, M. J., Salterio, S. E., \& Shearer, T. (2017). "Transparency" in Accounting and Corporate Governance: Making Sense of Multiple Meanings. Accounting and the Public Interest, 17(1), 31-59. https://doi.org/10.2308/apin-51746

Ter Bogt, H. J., \& Van Helden, G. J. (2000). Accounting change in Dutch government: exploring the gap between expectations and realizations. Management Accounting Research, 11(2), 263-279. https://doi.org/10.1006/mare.2000.0132

Townley, B. (2002). The role of competing rationalities in institutional change. Academy of Management Journal, 45(1), 163-179. https://doi.org/10.2307/3069290

Van der Tas, L. G. (1988). Measuring harmonisation of financial reporting practice, Accounting and business research, 18(70), 157-169. https://doi.org/10.1080/00014788.1988.9729361 
Walker, R. G. (2011). Issues in the preparation of public sector consolidated statements. Abacus, 47(4), 477-500. https://doi.org/10.1111/j.1467-6281.2011.00349.x

Yip, R. W., \& Young, D. (2012). Does mandatory IFRS adoption improve information comparability? The Accounting Review, 87(5), 1767-1789. https://doi.org/10.2308/accr-50192

\section{Copyrights}

Copyright for this article is retained by the author(s). with first publication rights granted to the journal.

This is an open-access article distributed under the terms and conditions of the Creative Commons Attribution license (http://creativecommons.org/licenses/by/4.0/). 